\title{
Application of Manganese-Based Materials in Aqueous Rechargeable Zinc-Ion Batteries
}

\begin{abstract}
Wanhong Zhang ${ }^{1 * t}$, Xiaoliang Zhai ${ }^{1+}$, Yansong Zhang ${ }^{2}$, Huijie Wei ${ }^{1}$, Junqing Ma ${ }^{1}$, Jing Wang ${ }^{1}$, Longlong Liang ${ }^{1}$, Yong Liu ${ }^{1,3 *}{ }^{*}$ Guangxin Wang ${ }^{1}$, Fengzhang Ren ${ }^{1}$ and Shizhong Wei ${ }^{1 *}$
\end{abstract}

\begin{abstract}
${ }^{1}$ National Joint Engineering Research Center for Abrasion Control and Molding of Metal Materials, School of Materials Science and Engineering, Henan University of Science and Technology, Luoyang, China, ${ }^{2}$ School of Food and Drug, Luoyang Normal University, Luoyang, China, ${ }^{3}$ Provincial and Ministerial Co-Construction of Collaborative Innovation Center for Non-Ferrous Metal New Materials and Advanced Processing Technology, Henan Key Laboratory of Non-Ferrous Materials Science \& Processing Technology, Henan University of Science and Technology, Luoyang, China
\end{abstract}

\section{OPEN ACCESS}

Edited by:

Cheng Zhong,

Tianjin University, China

Reviewed by:

Bin Liu,

Tianjin University, China

Lijie Ci,

Harbin Institute of Technology, China

*Correspondence:

Wanhong Zhang

zhangwh@haust.edu.cn

Yong Liu

liuyong209@haust.edu.cn

Shizhong Wei

wsz@haust.edu.cn

${ }^{\dagger}$ These authors have contributed equally to this work

Specialty section:

This article was submitted to Electrochemical Energy Conversion and Storage,

a section of the journa

Frontiers in Energy Research

Received: 31 May 2020

Accepted: 24 July 2020

Published: 02 September 2020

Citation:

Zhang W, Zhai $X$, Zhang Y, Wei $H$,

Ma J, Wang J, Liang L, Liu Y,

Wang G, Ren F and Wei S (2020)

Application of Manganese-Based Materials in Aqueous Rechargeable

Zinc-Ion Batteries.

Front. Energy Res. 8:195.

doi: 10.3389/fenrg.2020.00195
In recent years, aqueous rechargeable zinc-ion batteries (AZIBs) have attracted more and more attention not only because they use earth-abundant metals but also due to their improved safety and high volumetric energy density. As one type of promising electrode material for AZIBs, manganese-based materials are receiving considerable attention owing to their high theoretical specific capacity, non-toxicity, and low cost. This mini review summarizes the recent advances on the application of manganesebased materials (manganese oxide, manganate, and their composites) in AZIBs. In addition, the methods to enhance their zinc-ion storage properties are summarized and discussed, such as morphology engineering, doping, as well as compositing with other materials. Ultimately, some personal prospects for future research of the manganese-based materials for AZIBs are also proposed.

Keywords: manganese oxide, manganate, cathode materials, zinc-ion batteries, aqueous electrolyte

\section{INTRODUCTION}

In recent years, overconsumption of fossil fuels has caused many problems, such as global warming and environmental deterioration, which have been paid more and more attention by people all over the world (Liu et al., 2016, 2019c,d; He et al., 2017; Ma et al., 2017; Chen et al., 2019a; Guo et al., 2019c; Pan et al., 2020). Renewable energies like solar and wind energy are regarded as clean and sustainable ways to solve these issues. However, the intermittent nature of solar and wind energies greatly hinder their further development (Wang et al., 2019c; Xiao et al., 2019; Yuan et al., 2019; Zhao X. et al., 2019; Cheng et al., 2020; Ma J. Q. et al., 2020). Fortunately, electrochemical energy storage (EES) devices are regarded as a promising solution which could store electric energy obtained from renewable energies (Ding et al., 2018; Chen et al., 2019b; Li Y. et al., 2019; Li J. et al., 2020; Li Y. et al., 2020; Zhang et al., 2019; Ma J. Y. et al., 2020; Wang R. et al., 2020; Wang W. et al., 2020). Among various EES devices, lithiumion batteries have been intensively investigated and used in many applications such as portable electronics, electrical vehicles, and smart grids due to their high energy density, long cycle life, and environmental benignity (Wang F. et al., 2018; Wang F. et al., 2020; Wang G. et al., 2020; Hao et al., 2019; Liu et al., 2019f; Wu et al., 2019; Zhao Q. et al., 2019; Gao G. J. et al., 2020; Song et al., 2020; Zou et al., 2020). Nevertheless, the increasing concerns about limited lithium resources, high cost, and safety issue strongly limit their further development for large-scale 
applications (Liu et al., 2018; Ma X. D. et al., 2019; Wang et al., 2019d; Yixuan et al., 2020; Yu et al., 2020; Zhang et al., 2020). In addition, the other alkali metals, $\mathrm{Na}$ and $\mathrm{K}$, are extremely reactive and the introduced organic electrolytes are flammable, which bring great security risks for sodium-ion and potassiumion batteries (Song et al., 2018; Ding et al., 2019; Hua et al., 2019). Therefore, it is urgent to explore alternative battery systems with low cost, high safety, and long cycle life.

Aqueous rechargeable zinc-ion batteries (AZIBs), in particular, comprise of a zinc metal anode, the aqueous electrolyte in majority, and a cathode for accommodation of $\mathrm{Zn}$ ions. Significantly, it differs from the traditional alkaline $\mathrm{Zn}$ battery (such as $\mathrm{Zn}-\mathrm{Mn}$ or Ni-Zn battery) which is based on dissolution/precipitation reactions at the $\mathrm{Zn}$ anode and $\mathrm{H}^{+}$intercalation/extraction reactions at the cathode. Also, it is also distinguished from other batteries with $\mathrm{Zn}$ anode but no intercalation of $\mathrm{Zn}$ ions in cathode reactions (Kordesh and Weissenbacher, 1994; Song et al., 2018). Nowadays, AZIBs have attracted more and more attention not only because they use earth-abundant metals but also due to their improved safety and high volumetric energy density (Chen et al., 2017; Song et al., 2018). As a typical type of cathode materials for AZIBs, manganese-based materials are receiving considerable attention in recent years owing to their high theoretical specific capacity, non-toxicity, and low cost (Figures 1 A,B). For instance, Wu et al. (2018) recently reported an article about $\alpha-\mathrm{MnO}_{2}$ coated with graphene as a high-performance cathode material for AZIBs. By a simple hydrothermal method, Zhu et al. (2018) fabricated a flower-like $\mathrm{Mn}_{3} \mathrm{O}_{4}$ and used it as a cathode material of AZIBs. And Wan and Niu (2019) reviewed the design strategies of vanadium-based materials for AZIBs. However, there is still a lack of review to exclusively cover the state-of-the-art developments of manganese-based materials for AZIBs.

Herein, we will give an overview on manganese-based materials, mainly including manganese oxide, manganate, as well as their composite materials, and their application in the field of electrode materials for AZIBs. Their micro/nanostructures and electrochemical properties are systematically summarized. Furthermore, some reasonable suggestions to promote future breakthroughs were also presented.

\section{MANGANESE-BASED MATERIALS FOR AQUEOUS RECHARGEABLE ZINC-ION BATTERIES}

The electrochemical performances of manganese-based materials, such as manganese oxide, manganate, and their composites, as cathode materials for AZIBs are summarized in Table 1. The zinc-ion storage properties of manganese-based materials combined with carbon-based materials are significantly superior than those of pure manganese-based materials.

\section{Manganese Oxide}

Since manganese has a variety of valence states, it could form a series of manganese oxides, such as $\mathrm{MnO}_{2}$ (Alfaruqi et al., 2016), $\mathrm{Mn}_{3} \mathrm{O}_{4}$ (Zhu et al., 2018), etc. Due to their special structure, they could be used as cathode materials for AZIBs (Khamsanga et al., 2019; Palaniyandy et al., 2019).

\section{Manganese Dioxide}

Manganese dioxide has a variety of crystal structures, such as $\alpha-\mathrm{MnO}_{2}$ (Wu et al., 2018), $\beta-\mathrm{MnO}_{2}$ (Zhang et al., 2017), $\gamma-\mathrm{MnO}_{2}$ (Alfaruqi et al., 2015c), $\delta-\mathrm{MnO}_{2}$ (Khamsanga et al., 2019), etc., which are composed of the basic structural unit $\mathrm{MnO}_{6}$ octahedral into chain/tunnel/layered structure by sharing angle/edge and have been well applied in AZIBs (Song et al., 2018; Tang et al., 2019). However, the low electronic conductivity of $\mathrm{MnO}_{2}$ and large volume change of electrode during $\mathrm{Zn}^{2+}$ insertion/extraction process hinder the further development of $\mathrm{MnO}_{2}$ as the cathode material for AZIBs (Tang et al., 2019). At present, many researchers are devoted to improve the electronic conductivity of $\mathrm{MnO}_{2}$ and the cycling stability of $\mathrm{MnO}_{2}$-based AZIBs (Wu et al., 2018; Tang et al., 2019).

$\alpha-\mathrm{MnO}_{2}$, which have stable $2 \times 2$ tunnel structure, has received considerable attention in recent years as a cathode material for AZIBs (Figure 1C; Palaniyandy et al., 2019; Gao X. et al., 2020). In 2009, $\alpha-\mathrm{MnO}_{2}$ was first applied as a cathode material for AZIBs, and specific capacity reached $210 \mathrm{mAh}$ $\mathrm{g}^{-1}$ at $0.2 \mathrm{~A} \mathrm{~g}^{-1}$ (Xu et al., 2009). Pan et al. (2016) added $\mathrm{MnSO}_{4}$ into $\mathrm{ZnSO}_{4}$ electrolyte to suppress the dissolution of $\mathrm{Mn}^{2+}$ and stabilize the electrode. During the discharging process, $\mathrm{Zn}^{2+}$ and $\mathrm{H}^{+}$co-inserted into $\alpha-\mathrm{MnO}_{2}$, generating $\mathrm{ZnSO}_{4}\left[\mathrm{Zn}(\mathrm{OH})_{2}\right]_{3} \cdot \mathrm{xH}_{2} \mathrm{O}$ and $\mathrm{MnOOH}$, from which $\mathrm{Zn}^{2+}$ and $\mathrm{H}^{+}$could reversibly extract in the charging process. And these $\mathrm{Zn} / \alpha-\mathrm{MnO}_{2}$ batteries show excellent rate capability and high capacity retention of $92 \%$ after 5,000 cycles. To further enhance the zinc-ion storage properties of $\alpha-\mathrm{MnO}_{2}, \mathrm{Wu}$ et al. (2018) fabricated $\alpha-\mathrm{MnO}_{2}$ nanowires coated with graphene (MGS) by hydrothermal method (Figure 1D). The graphene not only increases the electronic conductivity of the material but also effectively inhibits the erosion of the electrolyte to electrode. During discharge and charging, the insertion of $\mathrm{Zn}^{2+}$ takes place in two steps, First, $\mathrm{Zn}^{2+}$ inserted into water layers and formed zinc-buserite, then continued to be inserted into $2 \times 2$ tunnels of $\alpha-\mathrm{MnO}_{2}$ (Figure 1E). These detailed studies provide a good theoretical basis for $\alpha-\mathrm{MnO}_{2}$ in AZIBs.

Compared with other manganese dioxide phases, $\beta-\mathrm{MnO}_{2}$ has the narrowest tunnel and minimal channel. The $1 \times 1$ tunnel $(2.3 \times 2.3 \AA)$ of the $\beta-\mathrm{MnO}_{2}$ hardly incorporates $\mathrm{Zn}^{2+}$ inserting (Figure 1F; Devaraj and Munichandraiah, 2008; Islam et al., 2017a; Zhang et al., 2017). However, $\beta-\mathrm{MnO}_{2}$ has high thermodynamic stability. Therefore, it has also been reported as a cathode material for AZIBs. For instance, Islam et al. (2017a) synthesized $\beta-\mathrm{MnO}_{2}$ nanorods exposed to (101) plane by a microwave-assisted hydrothermal method and used them as cathode materials for AZIBs. By a combination of in situ synchrotron, ex situ X-ray diffraction (XRD), and other techniques, the $\mathrm{Zn}$-ion storage mechanism has revealed that the reaction mechanism of the $\beta-\mathrm{MnO}_{2}$ nanorod electrode in the $\mathrm{Zn}$ cell proceeded via a combination of solid solution and conversion reactions, in which $\mathrm{Zn}$ ion intercalated into the $\beta-\mathrm{MnO}_{2}$ framework, followed by the formation of $\mathrm{Zn}$-inserted phases along with the precipitation of $\mathrm{ZnSO}_{4} \cdot 3 \mathrm{Zn}(\mathrm{OH})_{2} \cdot 5 \mathrm{H}_{2} \mathrm{O}$ 




FIGURE 1 | (A) The statistical table of manganese-based materials reported in aqueous rechargeable zinc-ion batteries (AZIBs). (B) The percentage of different manganese-based materials reported in AZIBs. (C) Schematic diagram of $\alpha-\mathrm{MnO}_{2}$ crystal structure. (D) Transmission electron microscopy (TEM) and corresponding selected area electron diffraction (SAED) of $\alpha-\mathrm{MnO}_{2} /$ graphene scrolls (MGS). (E) Schematic diagram of zinc ions inserting into the MGS electrode in two steps. (F) Schematic diagram of $\beta-\mathrm{MnO}_{2}$ crystal structure. (G) Schematic diagram of the $\mathrm{Zn} / \beta-\mathrm{MnO}_{2}$ batteries with $\beta-\mathrm{MnO}_{2}$ as cathode, $\mathrm{Zn}\left(\mathrm{CF}_{3} \mathrm{SO}_{3}\right)_{2}$ add $\left.\mathrm{Mn}\left(\mathrm{CF}_{3} \mathrm{SO}\right)_{3}\right)_{2}$ as electrolyte. (H) Discharge/charge profiles of $\mathrm{Zn} / \beta-\mathrm{MnO}_{2}$ batteries. (C) Reprinted with permission (Gao X. et al., 2020). Copyright 2020, WILEY-VCH. (D,E) Reprinted with permission (Wu et al., 2018). Copyright 2018, WILEY-VCH. (F-H) Reprinted with permission (Zhang et al., 2017). Copyright 2017, Springer Nature.

on the electrode surface. And the electrode shows a high discharge capacity of $270 \mathrm{~mA} \mathrm{~h} \mathrm{~g}^{-1}$ at $0.1 \mathrm{~A} \mathrm{~g}^{-1}$. Similarly, Zhang et al. (2017) synthesized $\beta-\mathrm{MnO}_{2}$ nanorods by a hydrothermal method and took $3 \mathrm{M} \mathrm{Zn}\left(\mathrm{CF}_{3} \mathrm{SO}_{3}\right)_{2}$ with $0.1 \mathrm{M} \mathrm{Mn}\left(\mathrm{CF}_{3} \mathrm{SO}_{3}\right)_{2}$ as electrolyte. As shown in Figure 1G, during the initial discharge, a phase transformed from tunneled structure to layered structure ( $\mathrm{Zn}$-buserite) and followed by reversible $\mathrm{Zn}^{2+}$ (de)intercalation in the $\mathrm{H}_{2} \mathrm{O}$-containing $\mathrm{Zn}$-buserite framework. $\mathrm{Mn}^{2+}$ dissolution can be effectively inhibited by the addition of $\mathrm{Mn}\left(\mathrm{CF}_{3} \mathrm{SO}_{3}\right)_{2}$ in which the amorphous $\mathrm{MnO}_{\mathrm{x}}$ in situ generated on the electrode surface. The electrode showed excellent rate performance, which maintained $100 \mathrm{mAh} \mathrm{g}^{-1}$, even the current density reached $32.5 \mathrm{C}$ (Figure $\mathbf{1 H}$ ).

Comprised of randomly arranged $1 \times 1$ (size $\sim 2.3 \times 2.3 \AA$, pyrolusite) and $1 \times 2($ size $\sim 2.3 \times 4.6 \AA$, ramsdellite $)$ tunnels, $\gamma-\mathrm{MnO}_{2}$ is suitable for $\mathrm{Zn}^{2+}$ intercalation/deintercalation. In 2003, Kumar and Sampath (2003) first applied $\gamma-\mathrm{MnO}_{2}$ as the positive electrode for AZIBs. Subsequently, various $\gamma-\mathrm{MnO}_{2}$ were reported and used as cathode materials for AZIBs. For example, Alfaruqi et al. (2015c) prepared tunnel mesoporous $\gamma-\mathrm{MnO}_{2}$ by simple redox reaction. As shown in Supplementary Figure S1C, during the discharge process, the tunnel-type $\gamma-\mathrm{MnO}_{2}$ transformed to three phases $\left(\mathrm{ZnMn}_{2} \mathrm{O}_{4}, \gamma-\mathrm{Zn}_{\mathrm{x}} \mathrm{MnO}_{2}\right.$, and $\mathrm{L}-\mathrm{Zn}_{\mathrm{y}} \mathrm{MnO}_{2}$ ), which was accompanied that $\mathrm{Mn}^{4+}$ was reduced to $\mathrm{Mn}^{3+}$ and $\mathrm{Mn}^{2+}$, respectively.

$\delta-\mathrm{MnO}_{2}$ is considered to be a favorable host for $\mathrm{Zn}^{2+}$ due to its unique layered structure (the interlayer spacing can reach up to $7.0 \AA$ ) (Corpuz et al., 2019; Guo et al., 2019b). Compared with $\alpha-\mathrm{MnO}_{2}, \beta-\mathrm{MnO}_{2}$, and $\gamma-\mathrm{MnO}_{2}$, another advantage of $\delta-\mathrm{MnO}_{2}$ is that there is no phase transition during $\mathrm{Zn}^{2+}$ insertion or extraction, which could prevent the capacity fading effectively. However, unstable structure during the cycling limits its further application. At present, refine grain (Han et al., 2017; Guo et al., 2019a), synthetized special 
TABLE 1 | Electrochemical performance of manganese-based materials as cathode materials for AZIBs.

\begin{tabular}{|c|c|c|c|c|c|c|}
\hline Material & $\begin{array}{l}\text { Current density } \\
\qquad\left(\mathrm{A} \mathrm{g}^{-1}\right)\end{array}$ & $\begin{array}{c}\text { Cycle } \\
\text { number (n) }\end{array}$ & $\begin{array}{c}\text { Voltage } \\
\text { window (V) }\end{array}$ & $\begin{array}{l}\text { Initial capacity } \\
\quad\left(\mathrm{mAh} \mathrm{g}^{-1}\right)\end{array}$ & $\begin{array}{l}\text { Post-cycle capacity } \\
\qquad\left(m A h \mathrm{~g}^{-1}\right)\end{array}$ & References \\
\hline $\mathrm{MnO}_{2}$ powder & 1.0 & 50 & - & $\sim 171$ & $\sim 171$ & Xu et al., 2009 \\
\hline$\alpha-\mathrm{MnO}_{2}$ & 0.1 & 50 & $0.8-1.8$ & $\sim$ & 96.8 & Guo et al., 2020 \\
\hline$\alpha-\mathrm{MnO}_{2}$ nanorods & 0.083 & 50 & $1.0-1.8$ & 233 & $\sim 160$ & Alfaruqi et al., 2015b \\
\hline $\mathrm{MnO}_{2} / \mathrm{a}-\mathrm{CNT}$ & 5.0 & 500 & $1.0-1.9$ & $\sim 110$ & $\sim 100$ & Xu et al., 2014 \\
\hline$\alpha-\mathrm{MnO}_{2}$ & 1.3 & 5,000 & - & $\sim 100$ & $\sim 92$ & Pan et al., 2016 \\
\hline $\mathrm{MnO}_{2} @ \mathrm{C}$ & 0.066 & 50 & $1.0-1.8$ & $\sim 220$ & 189 & Islam et al., 2017b \\
\hline MGS & 3.0 & 3,000 & $1.0-1.85$ & 154.6 & 145.3 & Wu et al., 2018 \\
\hline $\mathrm{MnO}_{2}$ & 1.0 & 1,000 & $0.8-1.8$ & 157.6 & 134 & Zhao K. et al., 2018 \\
\hline $\mathrm{MnO}_{2}$ & 0.1 & 50 & $1.0-1.8$ & $\sim 225$ & 97 & Alfaruqi et al., 2018 \\
\hline $\mathrm{MnO}_{2}$ & 1.0 & 100 & $1.0-1.8$ & $\sim 280$ & $\sim 220$ & Liu et al., 2019a \\
\hline$\alpha-\mathrm{MnO}_{2} / \mathrm{OLC}$ & 0.246 & 100 & $1.0-1.8$ & 181 & 168 & Palaniyandy et al., 2019 \\
\hline$\alpha-\mathrm{MnO}_{2}$ & 0.3 & 100 & $0.9-1.9$ & 62 & 103 & Poyraz et al., 2019 \\
\hline$\alpha-\mathrm{MnO}_{2}$ & 0.1 & 300 & $0.9-1.8$ & 240 & 140 & Gao X. et al., 2020 \\
\hline$\beta-\mathrm{MnO}_{2}$ nanorods & 0.1 & 50 & $1.0-1.8$ & $\sim 270$ & $\sim 150$ & Islam et al., 2017a \\
\hline$\beta-\mathrm{MnO}_{2}$ & - & 2,000 & $0.8-1.9$ & 144 & 135 & Zhang et al., 2017 \\
\hline $\mathrm{D}-\beta-\mathrm{MnO}_{2}$ & 0.5 & 300 & $0.8-1.8$ & 225 & 200 & Han et al., 2020 \\
\hline $\mathrm{MnO}_{2} @ \mathrm{CC}$ & 2.0 & 700 & $1.0-1.8$ & $\sim 100$ & $\sim 90$ & Deng et al., 2019 \\
\hline$\beta-\mathrm{MnO}_{2}$ & 0.1 & 100 & $1.0-1.8$ & 100 & $\sim 105$ & Guo et al., 2019b \\
\hline $\mathrm{D}-\beta-\mathrm{MnO}_{2}$ & 0.5 & 300 & $0.8-1.8$ & $\sim 210$ & $\sim 200$ & Han et al., 2020 \\
\hline $\mathrm{Ce}-\mathrm{MnO}_{2}$ & 1.54 & 100 & $1.0-1.8$ & 134 & $\sim 78$ & Wang et al., 2019a \\
\hline $\mathrm{MnO}_{2}$ - graphene & 10 & 300 & $0.8-1.8$ & $\sim 100$ & $\sim 64$ & Wang C. et al., 2020 \\
\hline $\mathrm{MnO}_{2} @ \mathrm{CFP}$ & 1.885 & 10,000 & $1.0-1.8$ & 50 & 70 & Sun et al., 2017 \\
\hline $\mathrm{Mg}_{1.8} \mathrm{Mn}_{6} \mathrm{O}_{12} \cdot 4.8 \mathrm{H}_{2} \mathrm{O}$ & 0.05 & 50 & $0.7-2.0$ & 98 & $\sim 85$ & Lee et al., 2013 \\
\hline $\mathrm{V}-\mathrm{MnO}_{2}$ & 0.066 & 100 & $1.0-1.8$ & 260 & $\sim 130$ & Alfaruqi et al., 2017 \\
\hline $\mathrm{P}-\mathrm{MnO}_{2}$ & 0.2 & 200 & $1.0-1.8$ & $\sim 290$ & 280 & Huang et al., 2018 \\
\hline $\mathrm{MBC}$ & 4.0 & 2,000 & $1.0-1.85$ & $\sim 130$ & $\sim 120$ & Qiu et al., 2018b \\
\hline $\mathrm{MnO}_{2}$-birnessite & 2.0 & 2,000 & $1.0-1.8$ & 164 & 134 & Qiu et al., 2018a \\
\hline $\mathrm{MnO}_{2} / \mathrm{CNT}$ & 0.155 & 100 & $1.0-1.8$ & $\sim 200$ & 145 & Zhao L. et al., 2018 \\
\hline $\mathrm{MnO}_{2}$ nanospheres & 3.0 & 2,000 & $1.0-1.85$ & 124 & $\sim 80$ & Wang et al., 2019b \\
\hline$\alpha-\mathrm{Mn}_{2} \mathrm{O}_{3}$ & 2.0 & 1,000 & $1.0-1.9$ & 73.6 & 82.2 & Jiang et al., 2017 \\
\hline $\mathrm{MnO}_{x} @ \mathrm{~N}-\mathrm{C}$ & 2.0 & 1,600 & $0.8-1.8$ & $\sim 100$ & 100 & Fu et al., 2018 \\
\hline $\mathrm{Mn}_{3} \mathrm{O} 4$ & 0.5 & 300 & $0.8-1.9$ & $\sim 45$ & $\sim 100$ & Hao et al., 2018 \\
\hline $\mathrm{SSWM} @ \mathrm{Mn}_{3} \mathrm{O}_{4}$ & 0.5 & 500 & $1.0-1.8$ & $\sim 120$ & $\sim 130$ & Zhu et al., 2018 \\
\hline $\mathrm{Mn}_{5} \mathrm{O}_{8} / \mathrm{NCm}$ & 0.2 & 110 & $1.0-1.8$ & $\sim 300$ & $\sim 150$ & Li D.-S. et al., 2019 \\
\hline $\mathrm{Mn}_{2} \mathrm{O}_{4} / \mathrm{Mn}_{2} \mathrm{O}_{3}$ & 0.5 & 300 & $0.8-1.9$ & 82.6 & $\sim 105$ & Yang et al., 2019 \\
\hline $\mathrm{C}-\mathrm{MnO}$ & 1.0 & 1,500 & $0.8-1.8$ & 117.2 & 116.4 & Zhu et al., 2020 \\
\hline $\mathrm{ZMO} / \mathrm{C}$ & 0.5 & 50 & $0.8-2.0$ & $\sim 90$ & $\sim 80$ & Zhang et al., 2016 \\
\hline $\mathrm{H}-\mathrm{ZnMn}_{2} \mathrm{O}_{4}$ & 0.1 & 300 & $0.8-1.9$ & $\sim 85$ & $\sim 100$ & Wu et al., 2017 \\
\hline $\mathrm{KMn}_{8} \mathrm{O}_{16}$ & 0.1 & 100 & $0.8-1.9$ & $\sim 130$ & 77 & Cui et al., 2018 \\
\hline $\mathrm{ZnMn}_{2} \mathrm{O}_{4} / \mathrm{NG}$ & 1.0 & 2,500 & $0.8-1.8$ & 76 & 74 & Chen et al., 2019c \\
\hline
\end{tabular}


TABLE 1 | Continued

\begin{tabular}{|c|c|c|c|c|c|c|}
\hline Material & $\begin{array}{l}\text { Current density } \\
\qquad\left(\mathrm{A} \mathrm{g}^{-1}\right)\end{array}$ & $\begin{array}{c}\text { Cycle } \\
\text { number (n) }\end{array}$ & $\begin{array}{c}\text { Voltage } \\
\text { window (V) }\end{array}$ & $\begin{array}{l}\text { Initial capacity } \\
\left(\mathrm{mAh}^{-1}\right)\end{array}$ & 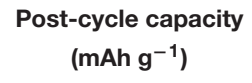 & References \\
\hline $\mathrm{Zn}_{1.67} \mathrm{Mn}_{1.33} \mathrm{O}_{4}$ & 0.1 & 40 & $0.8-1.9$ & $\sim 310$ & 175 & Lee et al., 2019 \\
\hline LMO-GN-CNT CNT & 0.296 & 600 & $1.4-2.1$ & 112 & 93 & Yuan et al., 2020 \\
\hline
\end{tabular}

AZIBs, aqueous rechargeable zinc-ion batteries; $\mathrm{MnO}_{2} / \mathrm{a}-\mathrm{CNT}$, the rod-like manganese dioxide/acid-treated carbon nanotube (a-CNT) nanocomposites; MnO ${ }_{2} @ C$, carbon-coated $\alpha-\mathrm{MnO}_{2}$ nanoparticles; MGS, $\alpha-\mathrm{MnO}_{2} /$ graphene scrolls; Ti-MnO $\mathrm{M}_{2} \mathrm{NWS}$, Ti-MnO $\mathrm{M}_{2}$ nanowires; $\alpha-\mathrm{MnO}_{2} / \mathrm{OLC}$, onion-like carbon integrated $\alpha-\mathrm{MnO}_{2}$ nanorods; $\mathrm{MnO}_{2} @ C C, \beta-\mathrm{MnO}_{2}$ nanolayer coated on carbon cloth; D- $\beta-\mathrm{MnO}_{2}, \beta-\mathrm{MnO}_{2}$ with rich oxygen defects; Ce-MnO $\mathrm{M}_{2}$, Ce-doped $\mathrm{MnO}_{2}$ nanorod; $M n \mathrm{O}_{2}-$ graphene, $\gamma-\mathrm{MnO}_{2}$-graphene composite; $\delta-\mathrm{MnO}_{2}-\mathrm{HN}$, hollow-structured $\delta-\mathrm{MnO}_{2} ; \delta-\mathrm{MnO}_{2}-\mathrm{NS}, \delta-\mathrm{MnO}_{2}$ nanosheets; $\delta-\mathrm{MnO}_{2}-\mathrm{NFG}, \delta-\mathrm{MnO}_{2}$ nanoflower/graphite composite; $\mathrm{V}-\mathrm{MnO}_{2}, \mathrm{~V}$-doped $\mathrm{MnO}_{2} ; \mathrm{P}-\mathrm{MnO}_{2}$, polyaniline-intercalated $\mathrm{MnO}_{2} ; \mathrm{MBC}$, manganese-based complex; $\mathrm{MnO}_{2} / \mathrm{CNT}, \mathrm{MnO} \mathrm{O}_{2} /$ carbon nanotube composites; MnO⿰亻NC, porous $\mathrm{MnOx}$ nanorods coated by $\mathrm{N}$-doped carbon; SSWM@Mn $\mathrm{O}_{4}$, stainless steel welded mesh@flower-like $\mathrm{Mn}_{3} \mathrm{O}_{4} ; \mathrm{Mn}_{5} \mathrm{O}_{8} / \mathrm{NCm}, \mathrm{Mn} \mathrm{O}_{8} / \mathrm{N}$-doped carbon composites; $\mathrm{ZMO} / \mathrm{C}, \mathrm{ZnMn}_{2} \mathrm{O}_{4}$ with carbon composite; $\mathrm{H}-\mathrm{ZnMn}_{2} \mathrm{O}_{4}$, hollow porous $\mathrm{ZnMn}_{2} \mathrm{O}_{4} ; \mathrm{ZNCMO} @ \mathrm{~N}-\mathrm{rGO}$, nickel and cobalt co-substituted $\mathrm{ZnMn} \mathrm{O}_{4}$ with $\mathrm{N}$-doped reduced graphene oxide composites; $L M O-G N-C N T, L i M_{2} \mathrm{O}_{4}$-graphene carbon nanotubes composite with the cross-linked conductive graphene; $D-\beta-M n \mathrm{O}_{2}$, $\beta-\mathrm{MnO}_{2}$ with oxygen defects; C-MO, carbon-coated $\mathrm{MnO}$.

morphology (Alfaruqi et al., 2015a; Guo et al., 2018), and add structural stabilizer (Kao-ian et al., 2019) are common ways to improve the performance of $\delta-\mathrm{MnO}_{2}$. For instance, Guo et al. (2019a) synthesized $\delta-\mathrm{MnO}_{2}$ nanosheets with a thickness of 2$4 \mathrm{~nm}$ by reduction of $\mathrm{KMnO}_{4}$. During the initial discharge process, $\mathrm{H}^{+}$inserted into the $\delta-\mathrm{MnO}_{2}$, followed by co-insertion of $\mathrm{Zn}^{2+}$ and $\mathrm{H}^{+}$. Ultrathin nanosheets shortened the diffusion path of $\mathrm{Zn}^{2+}$ and $\mathrm{H}^{+}$and improved the ion diffusion coefficient. The $\mathrm{Zn} / \delta-\mathrm{MnO}_{2}$ cells still showed $86 \mathrm{mAh} \mathrm{g}^{-1}$ at $0.5 \mathrm{~A} \mathrm{~g}^{-1}$, which show excellent cycle stability.

$\varepsilon-\mathrm{MnO}_{2}$ with face-shared $\mathrm{MnO}_{6}$ and $\mathrm{YO}_{6}$ octahedra (Y denotes vacancy) structure was also reported in AZIBs (Sun et al., 2017; Song et al., 2018). For instance, Sun et al. (2017) deposited $\mathrm{MnO}_{2}$ on the carbon fiber paper with no binder is required (Supplementary Figure S1E). They first reported that during the discharge process, $\mathrm{H}^{+}$and $\mathrm{Zn}^{2+}$ inserting corresponded to the generating of $\mathrm{MnOOH}$ and $\mathrm{ZnMn}_{2} \mathrm{O}_{4}$, respectively, in AZIBs.

Other manganese dioxides, such as $\lambda-\mathrm{MnO}_{2}$ and todorokitetype $\mathrm{MnO}_{2}$, have also been reported in AZIBs (Lee et al., 2013; Yuan et al., 2014). In 2014, Yuan et al. (2014) removed $\mathrm{Li}$ from $\mathrm{LiMn}_{2} \mathrm{O}_{4}$ with $\mathrm{H}_{2} \mathrm{SO}_{4}$ and synthesized $\lambda-\mathrm{MnO}_{2}$. The $\mathrm{Zn} / \lambda-\mathrm{MnO}_{2}$ cell displayed $442.6 \mathrm{mAh} \mathrm{g}^{-1}$ at $13.8 \mathrm{~mA} \mathrm{~g}^{-1}$. Lee et al. (2013) turned Na-birnessite into $\mathrm{Mg}$-containing solution and synthesized $\mathrm{Mg}_{1.8} \mathrm{Mn}_{6} \mathrm{O}_{12} \cdot 4.8 \mathrm{H}_{2} \mathrm{O}$ with todorokite-type structure. The cell could deliver specific capacity of $108 \mathrm{mAh} \mathrm{g}^{-1}$ at $0.5 \mathrm{C}\left(1 \mathrm{C}=255 \mathrm{~mA} \mathrm{~g}^{-1}\right)$.

\section{Other Manganese Oxides}

In addition to manganese dioxide, other manganese oxides such as $\mathrm{Mn}_{3} \mathrm{O}_{4}$ (Hao et al., 2018; $\mathrm{Zhu}$ et al., 2018), $\mathrm{Mn}_{2} \mathrm{O}_{3}$ (Jiang et al., 2017), and others (Fu et al., 2018) are also widely studied in AZIBs.

$\mathrm{Mn}_{2} \mathrm{O}_{3}$ is an alternative cathode material for AZIBs. In 2017, Jiang et al. (2017) first reported $\alpha-\mathrm{Mn}_{2} \mathrm{O}_{3}$ as the cathode material of AZIBs. The $\alpha-\mathrm{Mn}_{2} \mathrm{O}_{3}$ has a bixbyite structure. In this structure, the $\mathrm{Mn}^{3+}$ ions are in octahedral coordination and each oxygen ion is surrounded by four Mn ions. During the discharge process, the $\mathrm{Mn}^{3+}$ of $\mathrm{Mn}_{2} \mathrm{O}_{3}$ was reduced to $\mathrm{Mn}^{2+}$, accompanied the generation of $\mathrm{Zn}_{\mathrm{x}} \mathrm{Mn}_{2} \mathrm{O}_{3}$ without other phases generated. Based on this property, after 2,000 cycles, the $\alpha-\mathrm{Mn}_{2} \mathrm{O}_{3}$ displays a reversible discharge capacity of $38 \mathrm{mAh} \mathrm{g}^{-1}$ at $2 \mathrm{~A} \mathrm{~g}^{-1}$.
$\mathrm{Mn}_{3} \mathrm{O}_{4}$ has a mixed valence state of +2 and +3 , in which $\mathrm{Mn}^{2+}$ occupies the tetrahedral gap and $\mathrm{Mn}^{3+}$ occupies the octahedral gap. Inspired by multiple $\mathrm{Mn}$ valences may contribute to the diffusivity and migration of $\mathrm{Zn}^{2+}$ (Zhang et al., 2016; Ma J. L. et al., 2020). Zhu et al. (2018) synthesized a flower-like $\mathrm{Mn}_{3} \mathrm{O}_{4}$ on stainless steel welded mesh (SSWM@ $\mathrm{Mn}_{3} \mathrm{O}_{4}$ ) via a one-step hydrothermal method (Supplementary Figures S1A,B). They used ex situ XRD and ex situ scanning electron microscope to reveal the structure and morphology evolution of SSWM@ $\mathrm{Mn}_{3} \mathrm{O}_{4}$ electrode. During the discharge process, $\mathrm{Mn}^{3+}$ is reduced to $\mathrm{Mn}^{2+}$ and exists in the form of $\mathrm{MnO}$ after discharge. The $\mathrm{ZnSO}_{4}$ and $\mathrm{H}_{2} \mathrm{O}$ in the aqueous electrolyte react with the sequent $\mathrm{OH}^{-}$ions to form large flake-like $\mathrm{ZnSO}_{4}\left[\mathrm{Zn}(\mathrm{OH})_{2}\right]_{3} .5 \mathrm{H}_{2} \mathrm{O}$. Due to the intimate contact between the material and current collector, the SSWM@ $\mathrm{Mn}_{3} \mathrm{O}_{4}$ electrode shows great stability with higher than $100 \mathrm{mAh} \mathrm{g}^{-1}$ capacity at $0.1 \mathrm{~A} \mathrm{~g}^{-1}$ after 500 cycles.

In addition to the manganese oxides described above, some non-stoichiometric manganese oxides were also reported in AZIBs. For instance, Fu et al. (2018) synthesized N-doped carbon porous $\mathrm{MnO}_{\mathrm{x}}$ nanorods $\left(\mathrm{MnO}_{\mathrm{x}} @ \mathrm{~N}-\mathrm{C}\right)$ by using metal organic framework (MOF) materials. Amorphous carbon and onionlike nitrogen-doped carbon on the surface formed an electronic conductive network, which not only improves the electron conductivity but also alleviates the volume change caused by the insertion or extraction of $\mathrm{Zn}^{2+}$. Benefiting from the special structure, the electrode still could deliver $305 \mathrm{mAh} \mathrm{g}^{-1}$ after 600 cycles at $0.5 \mathrm{~A} \mathrm{~g}^{-1}$.

\section{Manganate}

Manganate is an important component of manganese-based materials. Some manganates are investigated as cathode materials for AZIBs, such as $\mathrm{LiMn}_{2} \mathrm{O}_{4}$ (Wu et al., 2015), $\mathrm{ZnMn}_{2} \mathrm{O}_{4}$ (Zhang et al., 2016; Wu et al., 2017; Chen et al., 2019c), $\mathrm{KMn}_{8} \mathrm{O}_{16}$ (Cui et al., 2018), and their derivatives (Tao et al., 2020).

Benefiting from the low cost, non-toxicity, easy fabrication, and high safety, $\mathrm{LiMn}_{2} \mathrm{O}_{4}$ has been well studied as a positive electrode material for lithium-ion batteries. Recently, this material has been also reported in AZIBs. For instance, Wu et al. (2015) investigated the effect of thiourea as the electrolyte additive on the electrochemical performance of AZIBs, using 
$\mathrm{LiMnO}_{4}$ as a cathode material. Similarly, $\mathrm{LiMnO}_{4}$ was also applied as a cathode material for AZIBs by Hoang et al. (2017) to study the suppression of zinc dendrite growth, in which pyrazole was used as an additive for the electrolyte.

Zhang et al. (2016) fabricated non-stoichiometric $\mathrm{ZnMn}_{2} \mathrm{O}_{4}$ /carbon composite and applied it as a cathode material for AZIBs. They found the unoccupied octahedral sites (8c) of the $\mathrm{ZnMn}_{2} \mathrm{O}_{4}$ have cation vacancies, which can provide additional pathways for $\mathrm{Zn}^{2+}$ migration (Supplementary Figure S1F). During the discharge process, $\mathrm{Zn}^{2+}$ inserted to the $\mathrm{Zn}-\mathrm{O}$ tetrahedron sites, while the charge process is opposite (Supplementary Figure S1D). Benefiting from the oxygen vacancy caused by cationic vacancies, the $\mathrm{ZnMn}_{2} \mathrm{O}_{4} /$ carbon electrode shows remarkable performance of $150 \mathrm{mAh} \mathrm{g}^{-1}$ at $50 \mathrm{~mA} \mathrm{\textrm {g } ^ { - 1 }}$ and an unprecedented capacity retention of $94 \%$ after 500 cycles at $0.5 \mathrm{~A} \mathrm{~g}^{-1}$ (Supplementary Figure S1G). Later, Cui et al. (2018) synthesized $\mathrm{KMn}_{8} \mathrm{O}_{16}$ microspheres by the hydrothermal method. During the initial charge process, partial $\mathrm{K}^{+}$extracted from $\mathrm{KMn}_{8} \mathrm{O}_{16}$. And in the following charge/discharge cycles, $\mathrm{Zn}^{2+}$ inserted or extracted from the electrode reversibly. The $\mathrm{Zn} / \mathrm{KMn}_{8} \mathrm{O}_{16}$ cell delivered $77.0 \mathrm{mAh}$ $\mathrm{g}^{-1}$ after 100 cycles and exhibited low self-discharge, indicating stable electrochemical performance.

\section{CONCLUSION AND OUTLOOK}

In summary, AZIBs have attracted considerable attention in recent years mainly due to their high safety, low cost, and high volumetric energy density. This mini review basically summarized the application of manganese-based materials, including manganese oxide, manganate, and their composite materials in AZIBs. Although tunnel or layered structures of manganese-based materials provide a path for $\mathrm{Zn}^{2+}$ insertion/extraction, the poor ionic and electrical conductivity restricts their further application. In this regard, it is particularly important to shorten the transport path of zinc ions and composite with materials with a high electronic conductivity. Hence, some aspects could be focused on to further improve the electrochemical performances of manganese-based AZIBs. And also some problems still exist and need to be resolved for their further development.

(1) $\mathrm{MnO}_{2}$ with different structures such as $\alpha, \beta, \gamma, \delta$, etc., has been well investigated as a cathode material for AZIBs. The mechanism of insertion or extraction properties of $\mathrm{Zn}^{2+}$ and their phase transformation during cycling are not clear enough and still need to be explored. In operando techniques, such as in situ X-ray technique, in situ electron microscopy, and in situ scanning probe technology, as well as synchron X-ray-based techniques, are very helpful to

\section{REFERENCES}

Alfaruqi, M. H., Gim, J., Kim, S., Song, J., Duong Tung, P., Jo, J., et al. (2015a). A layered delta-MnO2 nanoflake cathode with high zinc-storage capacities for eco-friendly battery applications. Electrochem. Commun. 60, 121-125. doi: 10.1016/j.elecom.2015.08.019 obtain time-dependent information. So, more research using in operando techniques needs to be conducted to get insight and understanding of the zinc-ion storage mechanism of manganesebased materials for AZIBs.

(2) Poor conductivity of $\mathrm{MnO}_{2}$ and volume change caused by phase transformation often lead to poor rate and cycling performances of the $\mathrm{Zn} / \mathrm{MnO}_{2}$ batteries. Special $\mathrm{MnO}_{2}$ morphologies such as nanospheres, core-shell structures, or nanowires growing on a conductive substrate such as carbon cloth/paper or stainless steel mesh will effectively solve these issues. Therefore, this research direction may deserve further study.

(3) Other manganese oxides (mainly includes $\mathrm{Mn}_{3} \mathrm{O}_{4}$, $\mathrm{Mn}_{2} \mathrm{O}_{3}$, and $\mathrm{MnO}_{\mathrm{x}}$ ) and manganate (such as $\mathrm{LiMn}_{2} \mathrm{O}_{4}$, $\mathrm{ZnMn}_{2} \mathrm{O}_{4}$, and $\mathrm{KMn}_{8} \mathrm{O}_{16}$ ) have also been reported for AZIBs, but compared to $\mathrm{MnO}_{2}$, more work on related materials as well as their zinc-ion storage mechanism should be further explored.

We hope this review is helpful and can inspire more innovative ideas for manganese-based or even transition metaloxide materials as cathode materials for AZIBs.

\section{AUTHOR CONTRIBUTIONS}

WZ, YL, and SW conceived the idea. YL and XZ wrote the draft. All authors contributed to the writing, discussion, and revision of the final version of the manuscript.

\section{FUNDING}

This work was supported by the Program for Changjiang Scholars and Innovative Research Team in University (IRT_16R21), the Chinese 02 Special Fund (2017ZX02408003), Open Fund of National Joint Engineering Research Center for Abrasion Control and Molding of Metal Materials (HKDNM201807), the Key Science and Technology Program of Henan Province (Grant No. 172102310551), Science Foundation for Youths of Henan University of Science and Technology (2013QN006), the Student Research Training Plan of Henan University of Science and Technology (2019031), and the National Undergraduate Innovation Entrepreneurship Training Program (202010464031).

\section{SUPPLEMENTARY MATERIAL}

The Supplementary Material for this article can be found online at: https://www.frontiersin.org/articles/10.3389/fenrg. 2020.00195/full\#supplementary-material

Alfaruqi, M. H., Gim, J., Kim, S., Song, J., Jo, J., Kim, S., et al. (2015b). Enhanced reversible divalent zinc storage in a structurally stable alpha- $\mathrm{MnO} 2$ nanorod electrode. J. Power Sources 288, 320-327. doi: 10.1016/j.jpowsour.2015. 04.140

Alfaruqi, M. H., Islam, S., Gim, J., Song, J., Kim, S., Duong Tung, P., et al. (2016). A high surface area tunnel-type alpha- $\mathrm{MnO} 2$ nanorod cathode by a simple 
solvent-free synthesis for rechargeable aqueous zinc-ion batteries. Chem. Phys. Lett. 650, 64-68. doi: 10.1016/j.cplett.2016.02.067

Alfaruqi, M. H., Islam, S., Mathew, V., Song, J., Kim, S., Duong Pham, T., et al. (2017). Ambient redox synthesis of vanadium-doped manganese dioxide nanoparticles and their enhanced zinc storage properties. Appl. Surf. Sci. 404, 435-442. doi: 10.1016/j.apsusc.2017.02.009

Alfaruqi, M. H., Islam, S., Putro, D. Y., Mathew, V., Kim, S., Jo, J., et al. (2018). Structural transformation and electrochemical study of layered $\mathrm{MnO} 2$ in rechargeable aqueous zinc-ion battery. Electrochim. Acta 276, 1-11. doi: 10.1016/j.electacta.2018.04.139

Alfaruqi, M. H., Mathew, V., Gim, J., Kim, S., Song, J., Baboo, J. P., et al. (2015c). Electrochemically induced structural transformation in a gamma$\mathrm{MnO} 2$ cathode of a high capacity zinc-ion battery system. Chem. Mater. 27, 3609-3620. doi: 10.1021/cm504717p

Chen, H. P., Liu, J. Q., Liu, P., Wang, Y. J., Xiao, H. Y., Yang, Q. F., et al. (2019a). Carbon-confined magnesium hydride nano-lamellae for catalytic hydrogenation of carbon dioxide to lower olefins. J. Catal. 379, 121-128. doi: 10.1016/j.jcat.2019.09.022

Chen, L., Chen, L., Zhai, W., Li, D., Lin, Y., Guo, S., et al. (2019b). Tunable synthesis of LixMnO2 nanowires for aqueous Li-ion hybrid supercapacitor with high rate capability and ultra-long cycle life. J. Power Sources 413, 302-309. doi: 10.1016/j.jpowsour.2018.12.026

Chen, L., Yang, Z., Qin, H., Zeng, X., and Meng, J. (2019c). Advanced electrochemical performance of $\mathrm{ZnMn} 2 \mathrm{O} 4 / \mathrm{N}$-doped graphene hybrid as cathode material for zinc ion battery. J. Power Sources 425, 162-169. doi: 10. 1016/j.jpowsour.2019.04.010

Chen, L.-N., Yan, M.-Y., Mei, Z.-W., and Mai, L.-Q. (2017). Research progress and prospect of aqueous zinc ion battery. J. Inorg. Mater. 32, 225-234. doi: 10.15541/jim20160192

Cheng, Y., Xiao, X., Pan, K. M., and Pang, H. (2020). Development and application of self-healing materials in smart batteries and supercapacitors. Chem. Eng. J. 380:122565. doi: 10.1016/j.cej.2019.122565

Corpuz, R. D., De Juan, L. M. Z., Praserthdam, S., Pomprasertsuk, R., Yonezawa, T., Mai Thanh, N., et al. (2019). Annealing induced a well-ordered single crystal delta-MnO2 and its electrochemical performance in zinc-ion battery. Sci. Rep. 9:15107. doi: 10.1038/s41598-019-51692-x

Cui, J., Wu, X., Yang, S., Li, C., Tang, F., Chen, J., et al. (2018). Cryptomelane-type $\mathrm{KMn} 8 \mathrm{O} 16$ as potential cathode material - for aqueous zinc ion battery. Front. Chem. 6:352. doi: 10.3389/fchem.2018.00352

Deng, Z., Huang, J., Liu, J., Ren, L., Zhu, L., Xiao, X., et al. (2019). beta-MnO2 nanolayer coated on carbon cloth as a high-activity aqueous zinc-ion battery cathode with high-capacity and long-cycle-life. Mater. Lett. 248, 207-210. doi: 10.1016/j.matlet.2019.04.036

Devaraj, S., and Munichandraiah, N. (2008). Effect of crystallographic structure of $\mathrm{MnO} 2$ on its electrochemical capacitance properties. J. Phys. Chem. C 112, 4406-4417. doi: 10.1021/jp7108785

Ding, H. B., Zhang, Q. F., Liu, Z. M., Wang, J., Ma, R. F., Fan, L., et al. (2018). TiO2 quantum dots decorated multi-walled carbon nanotubes as the multifunctional separator for highly stable lithium sulfur batteries. Electrochim. Acta 284, 314-320. doi: 10.1016/j.electacta.2018.07.167

Ding, J., Zhang, H., Zhou, H., Feng, J., Zheng, X., Zhong, C., et al. (2019). Sulfurgrafted hollow carbon spheres for potassium-ion battery anodes. Adv. Mater. 31:1900429. doi: 10.1002/adma.201900429

Fu, Y., Wei, Q., Zhang, G., Wang, X., Zhang, J., Hu, Y., et al. (2018). Highperformance reversible aqueous $\mathrm{Zn}$-ion battery based on porous MnOx nanorods coated by MOF-derived N-doped carbon. Adv. Energy Mater. 8:1801445. doi: 10.1002/aenm.201801445

Gao, G. J., Feng, W. J., Su, W. X., Wang, S. J., Chen, L. J., Li, M. M., et al. (2020). Preparation and modification of MIL-101(Cr) metal organic framework and its application in lithium-sulfur batteries. Int. J. Electrochem. Sci. 15, 1426-1436. doi: $10.20964 / 2020.02 .26$

Gao, X., Wu, H., Li, W., Tian, Y., Zhang, Y., Wu, H., et al. (2020). H+-insertion boosted alpha-MnO2 for an aqueous Zn-Ion battery. Small 16:1905842. doi: 10.1002/smll.201905842

Gou, L., Xue, D., Mou, K.-L., Zhao, S.-P., Wang, Y., Fan, X.-Y., et al. (2019). alpha-MnO2@In2O3 nanotubes as cathode material for aqueous rechargeable Zn-Ion battery with high electrochemical performance. J. Electrochem. Soc. 166, A3362-A3368. doi: 10.1149/2.0801914jes
Guo, C., Liu, H., Li, J., Hou, Z., Liang, J., Zhou, J., et al. (2019a). Ultrathin delta-MnO2 nanosheets as cathode for aqueous rechargeable zinc ion battery. Electrochim. Acta 304, 370-377. doi: 10.1016/j.electacta.2019.03.008

Guo, C., Zhou, Q., Liu, H., Tian, S., Chen, B., Zhao, J., et al. (2019b). A case study of beta-, and delta-MnO2 with different crystallographic forms on ionstorage in rechargeable aqueous zinc ion battery. Electrochim. Acta 324:134867. doi: 10.1016/j.electacta.2019.134867

Guo, X., Li, J., Jin, X., Han, Y., Lin, Y., Lei, Z., et al. (2018). A hollow-structured manganese oxide cathode for stable $\mathrm{Zn}-\mathrm{MnO} 2$ batteries. Nanomaterials 8:301. doi: 10.3390/nano8050301

Guo, X., Zhou, J., Bai, C., Li, X., Fang, G., and Liang, S. (2020). Zn/MnO2 battery chemistry with dissolution-deposition mechanism. Mater. Today Energy 16:100396. doi: 10.1016/j.mtener.2020.100396

Guo, X. T., Zhang, Y. Z., Zhang, F., Li, Q., Anjum, D. H., Liang, H. F., et al. (2019c). A novel strategy for the synthesis of highly stable ternary SiOx composites for Li-ion-battery anodes. J. Mater. Chem. A 7, 15969-15974. doi: 10.1039/ c9ta04062e

Han, M., Huang, J., Liang, S., Shan, L., Xie, X., Yi, Z., et al. (2020). Oxygen defects in $\beta-\mathrm{MnO} 2$ enabling high-performance rechargeable aqueous zinc/manganese dioxide battery. iScience 23:100797. doi: 10.1016/j.isci.2019.100797

Han, S.-D., Kim, S., Li, D., Petkov, V., Yoo, H. D., Phillips, P. J., et al. (2017). Mechanism of $\mathrm{Zn}$ insertion into nanostructured delta-MnO2: a nonaqueous rechargeable Zn metal battery. Chem. Mater. 29, 4874-4884. doi: 10.1021/acs. chemmater.7b00852

Hao, J., Mou, J., Zhang, J., Dong, L., Liu, W., Xu, C., et al. (2018). Electrochemically induced spinel-layered phase transition of $\mathrm{Mn} 3 \mathrm{O} 4$ in high performance neutral aqueous rechargeable zinc battery. Electrochim. Acta 259, 170-178. doi: 10. 1016/j.electacta.2017.10.166

Hao, X. G., Zhao, Q., Su, S. M., Zhang, S. Q., Ma, J. B., Shen, L., et al. (2019). Constructing multifunctional interphase between $\mathrm{Li}_{1.4} \mathrm{Al}_{0.4} \mathrm{Ti}_{1.6}\left(\mathrm{PO}_{4}\right)_{3}$ and Li Metal by magnetron sputtering for highly stable solid-state lithium metal batteries. Adv. Energy Mater. 9:1901604. doi: 10.1002/aenm.2019 01604

He, T. T., Wang, W., Chen, W., Chen, D. M., and Yang, K. (2017). Influence of In and $\mathrm{Sn}$ compositions on the reactivity of Al-Ga-In-Sn alloys with water. Int. J. Hydrogen Energy 42, 5627-5637. doi: 10.1016/j.ijhydene.2016.11.112

Hoang, T. K. A., The Nam Long, D., Cho, J. H., Su, J. Y. J., Lee, C., Lu, C., et al. (2017). Sustainable gel electrolyte containing pyrazole as corrosion inhibitor and dendrite suppressor for aqueous $\mathrm{Zn} / \mathrm{LiMn} 2 \mathrm{O} 4$ battery. ChemSusChem 10, 2816-2822. doi: 10.1002/cssc.201700441

Hua, Y., Li, X. X., Chen, C. Y., and Pang, H. (2019). Cobalt based metal-organic frameworks and their derivatives for electrochemical energy conversion and storage. Chem. Eng. J. 370, 37-59. doi: 10.1016/j.cej.2019.03.163

Huang, J., Wang, Z., Hou, M., Dong, X., Liu, Y., Wang, Y., et al. (2018). Polyanilineintercalated manganese dioxide nanolayers as a high-performance cathode material for an aqueous zinc-ion battery. Nat. Commun. 9:2906. doi: 10.1038/ s41467-018-04949-4

Islam, S., Alfaruqi, M. H., Mathew, V., Song, J., Kim, S., Kim, S., et al. (2017a). Facile synthesis and the exploration of the zinc storage mechanism of beta$\mathrm{MnO} 2$ nanorods with exposed (101) planes as a novel cathode material for high performance eco-friendly zinc-ion batteries. J. Mater. Chem. A 5, 23299-23309. doi: $10.1039 / \mathrm{c} 7 \mathrm{ta} 07170 \mathrm{a}$

Islam, S., Alfaruqi, M. H., Song, J., Kim, S., Duong Tung, P., Jo, J., et al. (2017b). Carbon-coated manganese dioxide nanoparticles and their enhanced electrochemical properties for zinc-ion battery applications. J. Energy Chem. 26, 815-819. doi: 10.1016/j.jechem.2017.04.002

Jiang, B., Xu, C., Wu, C., Dong, L., Li, J., and Kang, F. (2017). Manganese sesquioxide as cathode material for multivalent zinc ion battery with high capacity and long cycle life. Electrochim. Acta 229, 422-428. doi: 10.1016/j. electacta.2017.01.163

Kao-ian, W., Pornprasertsuk, R., Thamyongkit, P., Maiyalagan, T., and Kheawhom, S. (2019). Rechargeable zinc-ion battery based on choline chloride-urea deep eutectic solvent. J. Electrochem. Soc. 166, A1063-A1069. doi: 10.1149/2. 0641906jes

Khamsanga, S., Pornprasertsuk, R., Yonezawa, T., Mohamad, A. A., and Kheawhom, S. (2019). delta-MnO2 nanoflower/graphite cathode for rechargeable aqueous zinc ion batteries. Sci. Rep. 9:8441. doi: $10.1038 /$ s41598-019-44915-8 
Kordesh, K., and Weissenbacher, M. (1994). Rechargeable alkaline manganese dioxide/zinc batteries. J. Power Sources 51, 61-78. doi: 10.1016/0378-7753(94) 01955-X

Kumar, G. G., and Sampath, S. (2003). Electrochemical characterization of poly(vinylidenefluoride)-zinc triflate gel polymer electrolyte and its application in solid-state zinc batteries. Solid State Ion. 160, 289-300. doi: 10.1016/s01672738(03)00209-1

Lee, J., Ju, J. B., Cho, W. I., Cho, B. W., and Oh, S. H. (2013). Todorokite-type $\mathrm{MnO} 2$ as a zinc-ion intercalating material. Electrochim. Acta 112, 138-143. doi: 10.1016/j.electacta.2013.08.136

Lee, J.-W., Seo, S.-D., and Kim, D.-W. (2019). Comparative study on ternary spinel cathode $\mathrm{Zn}-\mathrm{Mn}-\mathrm{O}$ microspheres for aqueous rechargeable zinc-ion batteries. J. Alloys Compd. 800, 478-482. doi: 10.1016/j.jallcom.2019.06.051

Li, D.-S., Wu, S., Wang, Y.-F., Sun, M., Liu, W.-L., Ren, M.-M., et al. (2019). Manganese oxides/N-doped carbon particles with high capacity retention for aqueous rechargeable zinc battery. J. Nanopart. Res. 21:52. doi: 10.1007/s11051019-4491-8

Li, J., Zhang, W., Zhang, X., Huo, L., Liang, J., Wu, L., et al. (2020). Copolymer derived micro/meso-porous carbon nanofibers with vacancy-type defects for high-performance supercapacitors. J. Mater. Chem. A 8, 2463-2471. doi: 10. 1039/c9ta08850d

Li, Y., Xu, Y. X., Liu, Y., and Pang, H. (2019). Exposing $\{001\}$ crystal plane on hexagonal Ni-MOF with surface-grown cross-linked mesh-structures for electrochemical energy storage. Small 15:1902463. doi: 10.1002/smll.201902463

Li, Y., Zhai, X., Liu, Y., Wei, H., Ma, J., Chen, M., et al. (2020). WO3-based materials as electrocatalysts for hydrogen evolution reaction. Front. Mater. 7:105. doi: $10.3389 /$ fmats. 2020.00105

Lian, S., Sun, C., Xu, W., Huo, W., Luo, Y., Zhao, K., et al. (2019). Built-in oriented electric field facilitating durable $\mathrm{Zn}-\mathrm{MnO} 2$ battery. Nano Energy 62, 79-84. doi: 10.1016/j.nanoen.2019.04.038

Liu, F., Chen, Z., Fang, G., Wang, Z., Cai, Y., Tang, B., et al. (2019a). V2O5 nanospheres with mixed vanadium valences as high electrochemically active aqueous zinc-ion battery cathode. Nano Micro Lett. 11:25. doi: 10.1007/s40820019-0256-2

Liu, G., Huang, H., Bi, R., Xiao, X., Ma, T., and Zhang, L. (2019b). K+ preintercalated manganese dioxide with enhanced $\mathrm{Zn} 2+$ diffusion for high rate and durable aqueous zinc-ion batteries. J. Mater. Chem. A 7, 20806-20812. doi: $10.1039 /$ c9ta08049j

Liu, G. L., Cui, J., Luo, R. J., Liu, Y., Huang, X. X., Wu, N. T., et al. (2019c). 2D MoS2 grown on biomass-based hollow carbon fibers for energy storage. Appl. Surf. Sci. 469, 854-863. doi: 10.1016/j.apsusc.2018.11.067

Liu, X., Yuan, Y., Liu, J., Liu, B., Chen, X., Ding, J., et al. (2019d). Utilizing solar energy to improve the oxygen evolution reaction kinetics in zinc-air battery. Nat. Commun. 10:4767. doi: 10.1038/s41467-019-12627-2

Liu, Y., Wang, H. C., Yang, K. K., Yang, Y. N., Ma, J. Q., Pan, K. M., et al. (2019e). Enhanced electrochemical performance of $\mathrm{Sb} 2 \mathrm{O} 3$ as an anode for lithiumion batteries by a stable cross-linked binder. Appl. Sci. 9:2677. doi: 10.3390/ app9132677

Liu, Y., Wang, Y., Wang, F., Lei, Z. X., Zhang, W. H., Pan, K. M., et al. (2019f). Facile synthesis of antimony tungstate nanosheets as anodes for lithium-ion batteries. Nanomaterials 9:1689. doi: 10.3390/nano9121689

Liu, G. L., Li, M. L., Wu, N. T., Cui, L., Huang, X. X., and Liu, X. M. (2018). Singlecrystalline particles: an effective way to ameliorate the intragranular cracking, thermal stability, and capacity fading of the LiNi0.6Co0.2Mn0.2O2 electrodes. J. Electrochem. Soc. 165, A3040-A3047. doi: 10.1149/2.0491813jes

Liu, Z., Liu, C., Li, L. F., Qin, W., and Xu, A. R. (2016). CO2 separation by supported ionic liquid membranes and prediction of separation performance. Int. J. Greenhouse Gas Control 53, 79-84. doi: 10.1016/j.ijggc.2016.07.041

Ma, J. L., Ren, F. Z., Wang, G. X., Xiong, Y., Li, Y. Q., and Wen, J. B. (2017). Electrochemical performance of melt-spinning Al-Mg-Sn based anode alloys. Int. J. Hydrogen Energy 42, 11654-11661. doi: 10.1016/j.ijhydene.2017. 02.185

Ma, J. L., Zhang, Y., Qin, C. H., Ren, F. Z., and Wang, G. X. (2020). Effects of polystyrene sulfonate/graphene and $\mathrm{Mn3O} 4$ /graphene on property of aluminum(zinc)-air batteries. Int. J. Hydrogen Energy 45, 13025-13034. doi: 10.1016/j.ijhydene.2020.02.222

Ma, J. Q., Wei, H. J., Liu, Y., Ren, X. Y., Li, Y. X., Wang, F., et al. (2020). Application of $\mathrm{Co} 3 \mathrm{O} 4$-based materials in electrocatalytic hydrogen evolution reaction: a review. Int. J. Hydrogen Energy 41, 21205-21220. doi: 10.1016/j.ijhydene.2020. 05.280

Ma, J. Y., Guo, X. T., Xue, H. G., Pan, K. M., Liu, C. S., and Pang, H. (2020). Niobium/tantalum-based materials: synthesis and applications in electrochemical energy storage. Chem. Eng. J. 380:122428. doi: 10.1016/j.cej. 2019.122428

Ma, X. D., Xiong, X. H., Zou, P. J., Liu, W. Z., Wang, F., Liang, L. W., et al. (2019). General and scalable fabrication of core-shell metal Sulfides@C anchored on 3D N-doped foam toward flexible sodium ion batteries. Small 15:1903259. doi: 10.1002/smll.201903259

Palaniyandy, N., Kebede, M. A., Raju, K., Ozoemena, K. I., le Roux, L., Mathe, M. K., et al. (2019). alpha-Mno(2) nanorod/onion-like carbon composite cathode material for aqueous zinc-ion battery. Mater. Chem. Phys. 230, 258266. doi: 10.1016/j.matchemphys.2019.03.069

Pan, H., Shao, Y., Yan, P., Cheng, Y., Han, K. S., Nie, Z., et al. (2016). Reversible aqueous zinc/manganese oxide energy storage from conversion reactions. Nat. Energy 1:16039. doi: 10.1038/nenergy.2016.39

Pan, K., Wang, F., Wei, S., Siyal, S. H., Ren, Y., Xu, L., et al. (2020). Lowtemperature solution synthesis and characterization of enhanced titanium dioxide photocatalyst on tailored mesoporous $\gamma-\mathrm{Al}_{2} \mathrm{O}_{3}$ support. Compos. Commun. 19, 82-89. doi: 10.1016/j.coco.2020.02.009

Poyraz, A. S., Laughlin, J., and Zec, Z. (2019). Improving the cycle life of cryptomelane type manganese dioxides in aqueous rechargeable zinc ion batteries: the effect of electrolyte concentration. Electrochim. Acta 305, 423-432. doi: 10.1016/j.electacta.2019.03.093

Qiu, N., Chen, H., Yang, Z., Sun, S., and Wang, Y. (2018a). Low-cost birnessite as a promising cathode for high-performance aqueous rechargeable batteries. Electrochim. Acta 272, 154-160. doi: 10.1016/j.electacta.2018.04.012

Qiu, N., Chen, H., Yang, Z., Sun, S., and Wang, Y. (2018b). Synthesis of manganesebased complex as cathode material for aqueous rechargeable batteries. RSC Adv. 8, 15703-15708. doi: 10.1039/c8ra01982g

Song, C. K., Feng, W. J., Wang, X., and Shi, Z. J. (2020). Enhanced electrochemical performance of $\mathrm{Li}_{1.2} \mathrm{Mn}_{0.54} \mathrm{Ni}_{0.13} \mathrm{Co}_{0.13} \mathrm{O}_{2}$ cathode material with bamboo essential oil. Ionics 26, 661-672. doi: 10.1007/s11581-019-03233-9

Song, M., Tan, H., Chao, D., and Fan, H. J. (2018). Recent advances in Zn-ion batteries. Adv. Funct. Mater. 28:1802564. doi: 10.1002/adfm.201802564

Sun, W., Wang, F., Hou, S., Yang, C., Fan, X., Ma, Z., et al. (2017). Zn/MnO2 battery chemistry with $\mathrm{H}+$ and $\mathrm{Zn} 2+$ Coinsertion. J. Am. Chem. Soc. 139, 9775-9778. doi: 10.1021/jacs.7b04471

Tang, B., Shan, L., Liang, S., and Zhou, J. (2019). Issues and opportunities facing aqueous zinc-ion batteries. Energy Environ. Sci. 12, 3288-3304. doi: 10.1039/ C9EE02526J

Tao, Y., Li, Z., Tang, L., Pu, X., Cao, T., Cheng, D., et al. (2020). Nickel and cobalt Co-substituted spinel ZnMn2O4@N-rGO for increased capacity and stability as a cathode material for rechargeable aqueous zinc-ion battery. Electrochim. Acta 331:135296. doi: 10.1016/j.electacta.2019.135296

Wan, F., and Niu, Z. Q. (2019). Design strategies for vanadium-based aqueous zinc-ion batteries. Angew. Chem. Int. Ed. 58, 16358-16367. doi: 10.1002/anie. 201903941

Wang, C., Zeng, Y., Xiao, X., Wu, S., Zhong, G., Xu, K., et al. (2020). gamma-MnO2 nanorods/graphene composite as efficient cathode for advanced rechargeable aqueous zinc-ion battery. J. Energy Chem. 43, 182-187. doi: 10.1016/j.jechem. 2019.08.011

Wang, F., Liu, Y., Wei, H., Wang, G., Ren, F., Liu, X., et al. (2020). Graphene induced growth of Sb2WO6 nanosheets for high-performance pseudocapacitive lithium-ion storage. J. Alloys Compd. 839:155614. doi: 10. 1016/j.jallcom.2020.155614

Wang, F., Liu, Y., Zhao, Y. F., Wang, Y., Wang, Z. J., Zhang, W. H., et al. (2018). Facile synthesis of two-dimensional porous $\mathrm{MgCo} 2 \mathrm{O} 4$ nanosheets as anode for lithium-ion batteries. Appl. Sci. 8:22. doi: 10.3390/app8010022

Wang, G., Chen, C., Chen, Y. H., Kang, X. W., Yang, C. H., Wang, F., et al. (2020). Self-stabilized and strongly adhesive supramolecular polymer protective layer enables ultrahigh-rate and large-capacity lithium-metal anode. Angew. Chem. Int. Ed. 59, 2055-2060. doi: 10.1002/anie.201913351

Wang, J., Sun, X., Zhao, H., Xu, L., Xia, J., Luo, M., et al. (2019a). Superiorperformance aqueous zinc ion battery based on structural transformation of MnO2 by rare earth doping. J. Phys. Chem. C 123, 22735-22741. doi: 10.1021/ acs.jpcc.9b05535 
Wang, J., Wang, J.-G., Liu, H., Wei, C., and Kang, F. (2019b). Zinc ion stabilized $\mathrm{MnO} 2$ nanospheres for high capacity and long lifespan aqueous zinc-ion batteries. J. Mater. Chem. A 7, 13727-13735. doi: 10.1039/c9ta0 $3541 \mathrm{a}$

Wang, J. D., Xiao, X., Liu, Y., Pan, K. M., Pang, H., and Wei, S. Z. (2019c). The application of $\mathrm{CeO} 2$-based materials in electrocatalysis. J. Mater. Chem. A 7, 17675-17702. doi: 10.1039/c9ta04804a

Wang, R., Cao, X., Zhao, D., Zhu, L., Xie, L., Liu, J., et al. (2020). Wet-chemistry synthesis of Li4Ti5O12 as anode materials rendering high-rate Li-ion storage. Int. J. Energy Res. 44, 4211-4223. doi: 10.1002/er.5020

Wang, W., Sun, K., and Liu, H. (2020). Effects of different aluminum sources on morphologies and properties of ceramic floor tiles from red mud. Constr. Build. Mater. 241:118119. doi: 10.1016/j.conbuildmat.2020. 118119

Wang, X. W., Yang, C. H., Xiong, X. H., Chen, G. L., Huang, M. Z., Wang, J. H., et al. (2019d). A robust sulfur host with dual lithium polysulfide immobilization mechanism for long cycle life and high capacity Li-S batteries. Energy Storage Mater. 16, 344-353. doi: 10.1016/j.ensm.2018.06.015

Wu, B., Zhang, G., Yan, M., Xiong, T., He, P., He, L., et al. (2018). Graphene scroll-coated alpha-MnO2 nanowires as high-performance cathode materials for aqueous Zn-ion battery. Small 14:1703850. doi: 10.1002/smll.20170 3850

Wu, N., Shen, J., Sun, L., Yuan, M., Shao, Y., Ma, J., et al. (2019). Hierarchical $\mathrm{N}$-doped graphene coated 1D cobalt oxide microrods for robust and fast lithium storage at elevated temperature. Electrochim. Acta 310, 70-77. doi: 10.1016/j. electacta.2019.04.115

Wu, X., Li, Y., Li, C., He, Z., Xiang, Y., Xiong, L., et al. (2015). The electrochemical performance improvement of LiMn2O4/Zn based on zinc foil as the current collector and thiourea as an electrolyte additive. J. Power Sources 300, 453-459. doi: 10.1016/j.jpowsour.2015.09.096

Wu, X., Xiang, Y., Peng, Q., Wu, X., Li, Y., Tang, F., et al. (2017). Green-low-cost rechargeable aqueous zinc-ion batteries using hollow porous spinel $\mathrm{ZnMn} 2 \mathrm{O} 4$ as the cathode material. J. Mater. Chem. A 5, 17990-17997. doi: 10.1039/ c7ta00100b

Xiao, X., Zhang, G. X., Xu, Y. X., Zhang, H. L., Guo, X. T., Liu, Y., et al. (2019). A new strategy for the controllable growth of MOF@PBA architectures. J. Mater. Chem. A 7, 17266-17271. doi: 10.1039/c9ta05409j

$\mathrm{Xu}, \mathrm{C} ., \mathrm{Li}, \mathrm{B} ., \mathrm{Du}, \mathrm{H}$., and Kang, F. (2012). Energetic zinc ion chemistry: the rechargeable zinc ion battery. Angew. Chem. Int. Ed. 51, 933-935. doi: 10.1002/ anie. 201106307

Xu, C. J., Du, H. D., Li, B. H., Kang, F. Y., and Zeng, Y. Q. (2009). Reversible insertion properties of zinc ion into manganese dioxide and its application for energy storage. Electrochem. Solid State Lett. 12, A61-A65. doi: 10.1149/1. 3065967

Xu, D., Li, B., Wei, C., He, Y.-B., Du, H., Chu, X., et al. (2014). Preparation and characterization of $\mathrm{MnO} 2 /$ acid-treated $\mathrm{CNT}$ nanocomposites for energy storage with zinc ions. Electrochim. Acta 133, 254-261. doi: 10.1016/j.electacta. 2014.04.001

Yang, S., Zhang, M., Wu, X., Wu, X., Zeng, F., Li, Y., et al. (2019). The excellent electrochemical performances of $\mathrm{ZnMn2O} / \mathrm{Mn} 2 \mathrm{O} 3$ : the composite cathode material for potential aqueous zinc ion batteries. J. Electroanal. Chem. 832, 69-74. doi: 10.1016/j.jelechem.2018.10.051

Yixuan, L., Xiaoliang, Z., Yong, L., Huijie, W., Junqing, M., Min, C., et al. (2020). WO3-based materials as electrocatalysts for hydrogen evolution reaction. Front. Mater. 7:105. doi: 10.3389/fmats.2020.00105

Yu, M., Yin, Z., Yan, G., Wang, Z., Guo, H., Li, G., et al. (2020). Synergy of interlayer expansion and capacitive contribution promoting sodium ion storage in S, N-Doped mesoporous carbon nanofiber. J. Power Sources 449:227514. doi: 10.1016/j.jpowsour.2019.227514

Yuan, C. L., Zhang, Y., Pan, Y., Liu, X. W., Wang, G. L., and Cao, D. X. (2014). Investigation of the intercalation of polyvalent cations $(\mathrm{Mg} 2+, \mathrm{Zn} 2+)$ into lambda-MnO2 for rechargeable aqueous battery. Electrochim. Acta 116, 404-412. doi: 10.1016/j.electacta.2013.11.090

Yuan, G., Geng, M., Zhang, P., and Li, B. (2020). Hybrids of LiMn2O4 nanoparticles anchored on carbon nanotubes/graphene sheets as long-cyclelife cathode material for rechargeable hybrid aqueous batteries. J. Solid State Electrochem. 24, 601-607. doi: 10.1007/s10008-020-04504-6

Yuan, M. J., Guo, X. T., Liu, Y., and Pang, H. (2019). Si-based materials derived from biomass: synthesis and applications in electrochemical energy storage. J. Mater. Chem. A 7, 22123-22147. doi: 10.1039/c9ta06934h

Zhang, J., Dong, Y. N., Liu, Q. X., Zhou, M., Mi, G., and Du, X. G. (2019). Hierarchically alloyed Pd-Cu microarchitecture with tunable shapes: morphological engineering, and catalysis for hydrogen evolution reaction of ammonia borane. Int. J. Hydrogen Energy 44, 30226-30236. doi: 10.1016/j. ijhydene.2019.09.213

Zhang, N., Cheng, F., Liu, J., Wang, L., Long, X., Liu, X., et al. (2017). Rechargeable aqueous zinc-manganese dioxide batteries with high energy and power densities. Nat. Commun. 8:405. doi: 10.1038/s41467-017-00467-x

Zhang, N., Cheng, F., Liu, Y., Zhao, Q., Lei, K., Chen, C., et al. (2016). Cationdeficient spinel $\mathrm{ZnMn}_{2} \mathrm{O}_{4}$ cathode in $\mathrm{Zn}\left(\mathrm{CF}_{3} \mathrm{SO}_{3}\right)_{2}$ electrolyte for rechargeable aqueous Zn-ion battery. J. Am. Chem. Soc. 138, 12894-12901. doi: 10.1021/jacs. $6 \mathrm{~b} 05958$

Zhang, Y., Chen, L., Hao, C., Zheng, X., Guo, Y., Chen, L., et al. (2020). Potassium pre-inserted $\mathrm{K}_{1.04} \mathrm{Mn}_{8} \mathrm{O}_{16}$ as cathode materials for aqueous $\mathrm{Li}$-ion and $\mathrm{Na}$-ion hybrid capacitors. J. Energy Chem. 46, 53-61. doi: 10.1016/j.jechem.2019.10.015

Zhao, K., Wang, C., Yu, Y., Yan, M., Wei, Q., He, P., et al. (2018). Ultrathin surface coating enables stabilized zinc metal anode. Adv. Mater. Interfaces 5:1800848. doi: 10.1002/admi.201800848

Zhao, L., Dong, L., Liu, W., and Xu, C. (2018). Binary and ternary manganese dioxide composites cathode for aqueous zinc-ion battery. Chemistryselect 3, 12661-12665. doi: 10.1002/slct.201802954

Zhao, Q., Hao, X. G., Su, S. M., Ma, J. B., Hu, Y., Liu, Y., et al. (2019). Expandedgraphite embedded in lithium metal as dendrite-free anode of lithium metal batteries. J. Mater. Chem. A 7, 15871-15879. doi: 10.1039/c9ta04240g

Zhao, X., Chen, H. L., Kong, F. G., Zhang, Y. J., Wang, S. J., Liu, S. X., et al. (2019). Fabrication, characteristics and applications of carbon materials with different morphologies and porous structures produced from wood liquefaction: a review. Chem. Eng. J. 364, 226-243. doi: 10.1016/j.cej.2019.01.159

Zhu, C., Fang, G., Liang, S., Chen, Z., Wang, Z., Ma, J., et al. (2020). Electrochemically induced cationic defect in $\mathrm{MnO}$ intercalation cathode for aqueous zinc-ion battery. Energy Storage Mater. 24, 394-401. doi: 10.1016/j. ensm.2019.07.030

Zhu, C., Fang, G., Zhou, J., Guo, J., Wang, Z., Wang, C., et al. (2018). Binder-free stainless steel@Mn3O4 nanoflower composite: a high-activity aqueous zinc-ion battery cathode with high-capacity and long-cycle-life. J. Mater. Chem. A 6, 9677-9683. doi: 10.1039/c8ta01198b

Zou, P., Lin, Z., Fan, M., Wang, F., Liu, Y., and Xiong, X. (2020). Facile and efficient fabrication of $\mathrm{Li}_{3} \mathrm{PO}_{4}$-coated Ni-rich cathode for high-performance lithium-ion battery. Appl. Surf. Sci. 504:144506. doi: 10.1016/j.apsusc.2019. 144506

Conflict of Interest: The authors declare that the research was conducted in the absence of any commercial or financial relationships that could be construed as a potential conflict of interest.

Copyright (c) 2020 Zhang, Zhai, Zhang, Wei, Ma, Wang, Liang, Liu, Wang, Ren and Wei. This is an open-access article distributed under the terms of the Creative Commons Attribution License (CC BY). The use, distribution or reproduction in other forums is permitted, provided the original author(s) and the copyright owner(s) are credited and that the original publication in this journal is cited, in accordance with accepted academic practice. No use, distribution or reproduction is permitted which does not comply with these terms. 